\section{Transfusion Medicine and Hemotherapy}

\author{
Review Article - Übersichtsarbeit
}

Transfus Med Hemother 2007;34:6-19

DOI: $\underline{10.1159 / 000098178}$
Received: December 8, 2006

Accepted: December 13, 2006

Published online: January 16, 2007

\title{
Inherited and Acquired Disorders of Platelet Function
}

\author{
Kerstin Jurk Beate E. Kehrel \\ Department of Anaesthesiology and Intensive Care, Experimental and Clinical Haemostasis, University Hospital Münster, Germany
}

\section{Key Words}

Platelets · Platelet disorders · Bleeding · Thrombosis

\section{Summary}

Platelet function defects are caused by rare congenital or, more frequently, by acquired disorders. They may lead to bleeding or thrombotic tendencies despite of normal platelet counts. The corresponding symptoms are often quite heterogeneous. A disorder of platelet function is suspected on the basis of case and family history, physical examination and platelet function tests. The so far primary screen of platelet dysfunctions, the bleeding time, is neither very sensitive nor specific and depends very much on the skills of the person that performs the test. Therefore, other general and in addition more specialised laboratory tests have to be performed for diagnosing an isolated platelet abnormality or in most cases combined platelet function defects. An approach to diagnosing a platelet disorder is presented, which supports the high significance of flow cytometry in platelet function analysis. Furthermore, we like to elucidate that in most cases a platelet-mediated haemostatic disorder cannot be characterised by just a single function defect, but rather by a combination of platelet functional abnormalities. Detailed knowledge of the platelet disorder is necessary for adequate therapeutical management of the individual patient, including the control of the underlying disease in acquired disorders, transfusion of platelets and administration of haemostatic drugs.

\author{
Schlüsselwörter \\ Thrombozyten - Thrombozytopathien . \\ Blutungsneigung · Thrombose
}

\section{Zusammenfassung}

Funktionsstörungen der Thrombozyten sind in seltenen Fällen angeboren und in den meisten Fällen erworbene Funktionsstörungen. Trotz normaler Thrombozytenzahl können sie zu Blutungsneigungen oder thrombotischen Komplikationen mit unterschiedlicher Symptomausprägung führen. Richtungsweisend für einen Verdacht auf einen Thrombozytenfunktionsdefekt sind neben dem klinischen Befund und der ausführlichen Anamnese, die Durchführung von Thrombozytenfunktionsuntersuchungen. Der bisher favorisierte Laborparameter, die Blutungszeit, ist weder besonders sensitiv noch spezifisch, und die Reproduzierbarkeit dieses Tests hängt sehr von der durchführenden Person ab. Für die Diagnose eines isolierten oder, wie in den meisten Fällen, eines kombinierten Thrombozytendefekts sollten deshalb weitere generelle sowie spezielle Labortests durchgeführt werden. Diese Übersicht stellt eine Vorgehensweise für die Diagnose eines Thrombozytenfunktionsdefekts vor, die den hohen Stellenwert der Durchflusszytometrie für die Thrombozytenfunktionsanalyse hervorhebt. Zudem soll diese Übersicht verdeutlichen, dass thrombozytenvermittelte Gerinnungsstörungen meist nicht nur durch einen, sondern durch eine Kombination von thrombozytären Funktionsdefekten charakterisiert sind. Eine adäquate individuelle Therapie erfordert die genaue Kenntnis der Thrombozytenanomalie und umfasst die primäre Therapie der zugrunde liegenden Erkrankung bei erworbenen Thrombozytenfunktionsstörungen, die Transfusion von Thrombozyten und die Medikation mit gerinnungsfördernden oder gerinnungshemmenden Präparaten.

\begin{tabular}{|c|c|}
\hline KARGER & (C) 2007 S. Karger GmbH, Freiburg \\
\hline $\begin{array}{l}\text { Fax +49 } 7614520714 \\
\text { E-mail Information@Karger.de } \\
\text { www.karger.com }\end{array}$ & $\begin{array}{l}\text { Accessible online at: } \\
\text { www.karger.com/tmh }\end{array}$ \\
\hline
\end{tabular}

Prof. Dr. Beate E. Kehrel

Department of Anaesthesiology and Intensive Care, Experimental and Clinical Haemostasis University Hospital Münster

Mendelstr. 11, 48149 Münster, Germany

Tel. +49 251 835-6725, Fax -2441

E-mail kehrel@uni-muenster.de 


\section{Introduction}

Intact haemostasis involves a tightly regulated interplay of platelets with platelets, other blood or vascular cells as well as with subendothelial matrix and plasma proteins. Therefore, platelet function defects contribute to bleeding or thrombotic complications.

Inherited defects of platelet function, although rare, have provided important insights into platelet physiology and pathology. Acquired defects are more common, but less well studied and often more complex and therefore more difficult to classify. They occur in a wide variety of clinical settings, e.g. autoimmune disorders, drug treatment, systemic diseases or surgery (table 1), and the severity of bleeding or thrombotic tendency varies greatly. In acquired platelet defects, the treatment is primarily directed at the underlying disease process in order to remove the cause of the platelet dysfunction.

A disorder of platelet function is suspected on the basis of case and family history, physical examination and platelet function tests (fig. 1). This review focuses on disorders which are caused by or associated with platelet function defects. Furthermore, we like to elucidate that in most cases a plateletmediated haemostatic disorder cannot be characterised by just a single function defect, but rather by a combination of platelet functional abnormalities.

\section{Defects of Platelet Adhesion}

If a blood vessel becomes injured or damaged the subendothelium is exposed to circulating blood cells. Platelets are the first and central haemostatic cells which adhere to subendothelial matrix proteins via specific receptors. Under high arterial shear conditions the platelet glycoprotein complex $\mathrm{GPIb} / \mathrm{V} / \mathrm{IX}$ predominantly mediates the first contact to the matrix-absorbed plasma protein von Willebrand factor (vWF) and thrombospondin-1 (TSP-1) $[1,2]$. In vessels with low or moderate shear stress, interactions of platelet GPIa/IIa with matrix exposed collagen and with immobilised fibronectin or fibrinogen induce platelet adhesion. Among this, interactions between vitronectin and $\alpha_{v} \beta_{3}$-integrin, fibronectin and $\alpha_{5} \beta_{1}$-integrin and laminin and $\alpha_{6} \beta_{1}$-integrin have been implicated in platelet adhesion [3,4]. There is a wide variety of inherited and acquired disorders with impaired interactions between platelets and the vessel wall which are caused by functional defects of adhesion receptors on the platelet surface or adhesive proteins from the plasma and/or subendothelial matrix.

\section{Hereditary Disorders}

The rare Bernard-Soulier syndrome (BSS, autosomal recessive inheritance) is characterised by missing or functional abnor- mal platelet GPIb/V/IX complexes leading to absent or markedly reduced adhesion and agglutination/aggregation in response to ristocetin or low concentrations of thrombin. However, aggregation induced by ADP, epinephrine or collagen appears normal. Patients with BSS often have giant platelets and mild or moderate thrombocytopenia. [5, 6]. Typical clinical features are nosebleed, subcutaneous haematoma, epistaxis, hypermenorrhoe, petechiae and purpura. Heterozygotes are often asymptomatic [7]. Adhesion and aggregation studies are not sufficient to identify patients with BSS. In addition, flow cytometric quantitative and functional analyses of the GPIb/V/IX complex and its subunits are necessary to distinguish between BSS and von Willebrand's disease and, in the case of BSS, to differentiate between quantitative and qualitative abnormalities of the GPIb/V/IX complex. It is well accepted that genetic defects in the genes of GPIb $\alpha$, GPIb $\beta$ or GPIX contributes to BSS [8]. In contrast, it has been proposed that a defect in GPV (not seen in humans yet) is associated with thrombotic rather than with bleeding tendency [9]. In case of severe bleeding, platelet transfusions may be recommended. Successful treatment of individual BSS cases with recombinant factor VIIa (FVIIa) implies a further promising indication of recombinant FVIIa [10].

A more common platelet adhesion disorder is the von Willebrand's disease (vWD). A detailed description is beyond the scope of this review. The readers are referred to Sadler [11]. The pathophysiology of vWD is highly variable and includes total absence of vWF (type 3, autosomal dominant inheritance) in the plasma and in platelets up to low production or defective release of intact $\mathrm{vWF}$ (type 1, autosomal dominant inheritance) as well as normal release of dysfunctional vWF with abnormal patterns of vWF multimers (type 2, autosomal dominant and/or recessive inheritance) [12]. Pseudo-vWD or platelet-type vWD is caused by defects in the gene of GPIb $\alpha$ which lead to an increased avidity of resting platelets for vWF with subsequent platelet activation and aggregation. Thus, the highly active high-molecular weight multimers of vWF are preferentially removed which hence may cause bleeding tendency, including prolonged bleeding time and intermittent thrombocytopenia. In vWD type $2 \mathrm{~B}$ (mutation in the $\mathrm{vWF}$ gene) the same symptoms are observed as in platelet-type vWD. Laboratory tests in both disorders are characterised by increased platelet adhesion and aggregation in response to low concentrations of ristocetin [13]. Platelet plasma exchange tests give the first hint whether GPIb on the platelet or the vWF is defect.

Specific diagnostics of vWD may require quantification of ristocetin cofactor, vWF collagen binding, analysis of vWF multimers and functional platelet analysis by flow cytometry including plasma exchange experiments, platelet adhesion analysis under flow conditions and molecular biology.

The frequent vWD type 1 is characterised by mild bleeding tendency, is often asymptomatic or becomes symptomatic only after surgery. Patients with vWD type 2 or 3 show severe but 
Table 1. Classification of platelet function disorders

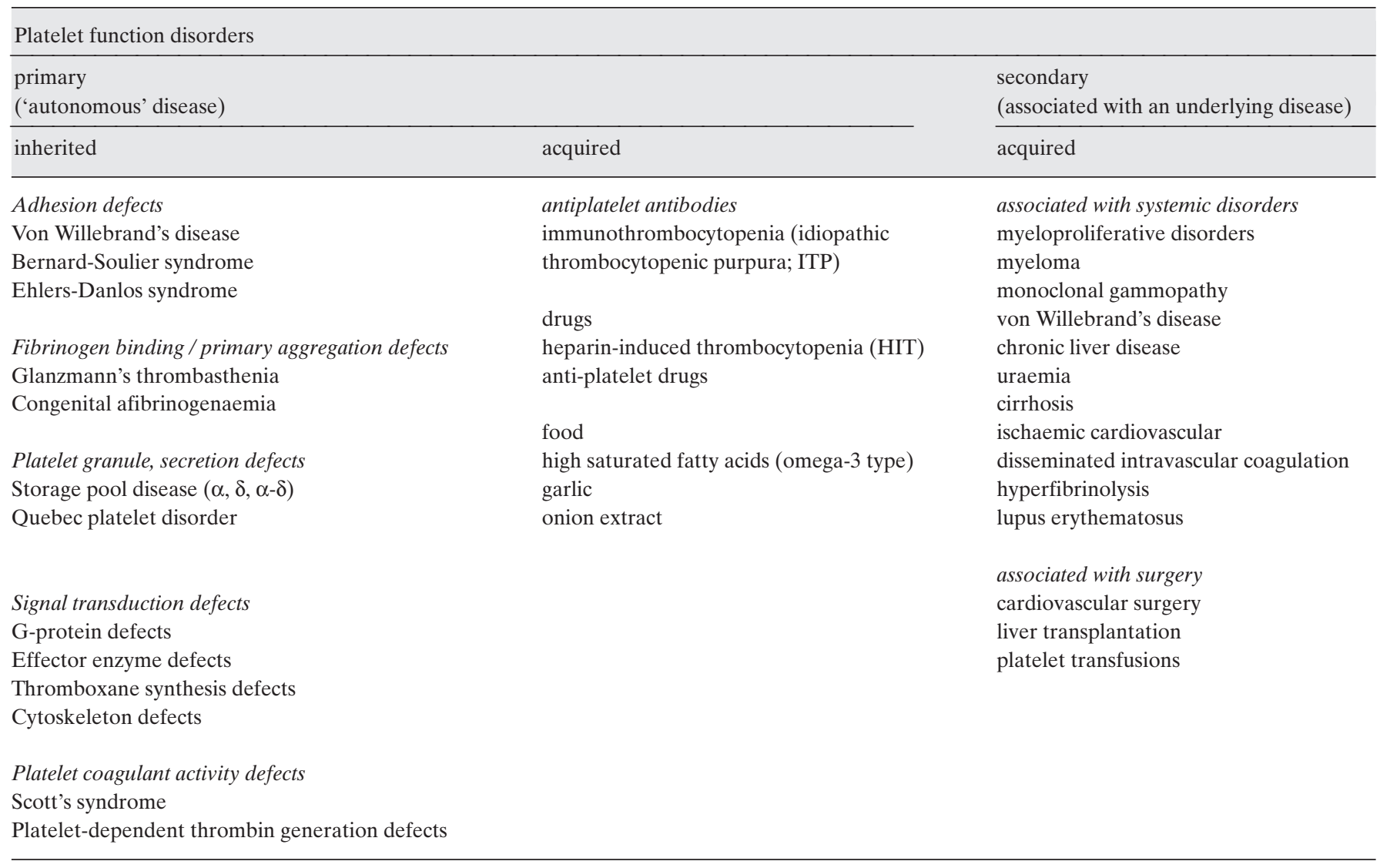

variable bleeding symptoms. Desmopressin, raising the plasma levels of vWF and FVIII released from endogenous stores, is often used in the case of vWD type 1 but is not useful in the cases of vWD type 3 , type $2 \mathrm{~A}, 2 \mathrm{M}$ and $2 \mathrm{~N}$, and contra-indicated in the case of vWD type $2 \mathrm{~B}$ with thrombocytopenia. In vWD type 3 vWF and FVIII concentrates may be given [14]. Recently, a two-step model of collagen interaction with platelets involving recognition of specific sequences in collagen by the integrin GPIa/IIa to arrest platelets under flow, which precedes the following GPVI-mediated platelet activation (see below) is discussed [15].

Loss or defects in the major collagen receptors GPIa/IIa $\left(\alpha_{2} \beta_{1^{-}}\right.$ integrin) and the immune receptor homologue GPVI showed impaired adhesion to collagen and vascular endothelium. Nieuwenhuis et al. [16] and Kehrel et al. [17] described patients with mild bleeding disorders with prolonged bleeding time attributable to deficient expression of platelet GPIa/IIa. The platelets from these patients had impaired collagen-induced aggregation but responded normally to all other platelet agonists. At least 8 patients with mild bleeding disorders have been described whose platelets showed functional deficiency in GPVI $[18,19]$. GPVI-deficient human platelets show selective impairment in collagen response. Collagen in- duced fibrinogen binding to GPVI-deficient platelets, but these platelets did not aggregate [20]. One of the GPVI-deficient patients developed antibodies to GPVI, which, when added to normal platelets, caused their aggregation and whose Fab fragments were able to reduce platelet aggregation induced by collagen [21]. GPVI-deficient platelets showed defective second-phase adhesion in flowing blood, a reaction that is attributable mainly to platelet-platelet interaction [22].

Generally platelet-dependent adhesion defects may be analysed by using the 'cone and plate(let) analyser' or Impact device, which enables shear-dependent platelet adhesion to a wide variety of adhesive substrates. In addition, qualitative and quantitative flow cytometric analysis of platelet collagen receptors using antigen-specific monoclonal antibodies is reliable to identify defects in adhesion mechanisms.

Patients with Ehlers-Danlos syndrome have impaired collagen synthesis leading to disrupted, defective vessels and to extremely fragile skin and easy bruising. Severe forms are predisposed to sudden death due to spontaneous bleeding as a result of arterial rupture. Platelets from these patients are functionally normal, but adhesion to the collagen in the vessel wall is impaired [23]. 


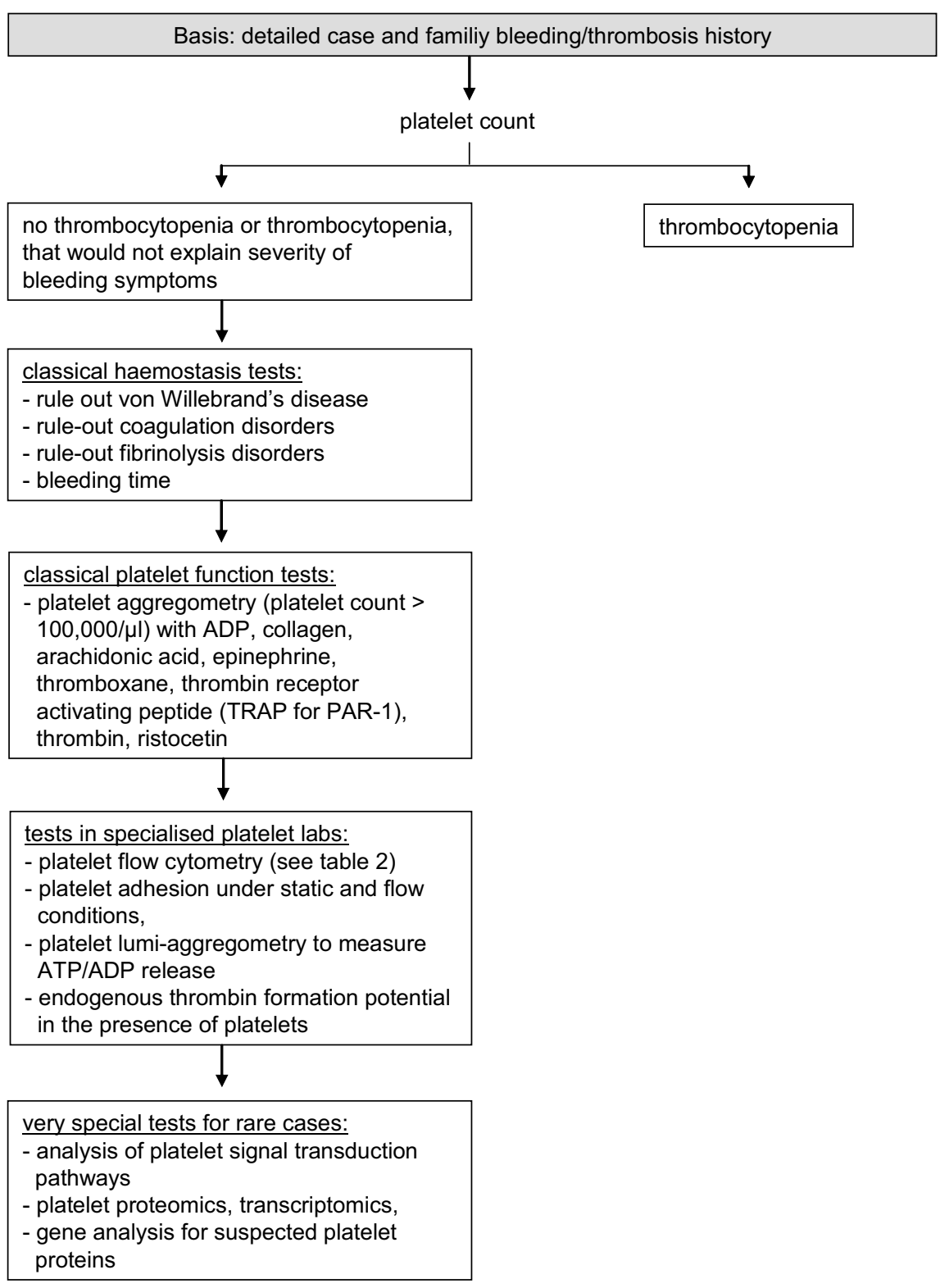

Fig. 1. Approach to diagnosing a platelet disorder.

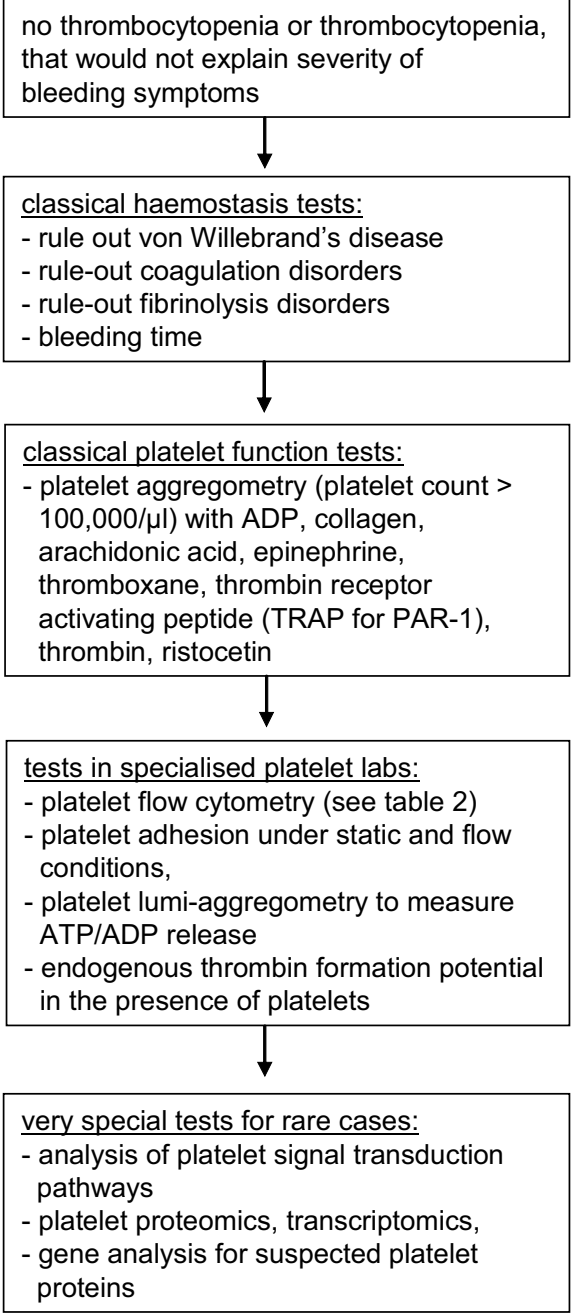

\section{Acquired Disorders}

Acquired $v W D$ is often associated with systemic disorders such as uraemia, myeloproliferative disorders, certain tumours and monoclonal gammopathies, inducing abnormalities of plasma or platelet vWF.

Uraemic patients usually have normal or increased plasma levels of vWF. However, the level of high-molecular vWF multimers is significantly decreased in these patients, leading to dysfunctional platelet adhesion. Desmopressin has been shown to shorten the bleeding time in $75 \%$ of uraemic patients $[24,25]$.

Up to $50 \%$ of patients with myeloproliferative disorders show qualitative or quantitative changes of plasma vWF [26]. Thrombocytosis is often associated with a significant decrease of high-molecular vWF multimers and an increase of vWF fragments in the plasma. The causal link is still not known, but recent studies indicate that pathologically elevated concentrations of pre-activated platelets lead to an increased binding of high-molecular vWF multimers to the platelet surface with subsequent degradation of bound $\mathrm{vWF}$ via platelet-secreted proteases. This acquired vWD phenotype seems to be similar to type 2 and platelet-type $\mathrm{vWD}$, and therefore desmopressin or $\mathrm{VWF}$ concentrates do not correct the haemostatic defect [27]. Platelet vWF may also be involved in the bleeding tendency of patients with bypass surgery [28]. Some patients have low platelet vWF activity, usually associated with higher or normal values of $\mathrm{vWF}$ antigen, whereas plasma levels are normal or modestly decreased [29]. Aortic stenosis has also been reported to be associated with acquired vWD. Shear stress across the narrowed valve is thought to induce structural changes of large vWF multimers degraded by ADAMTS-13- 
Fig. 2. Platelet function defects in Glanzmann's thrombocytopenia. Scanning electron microscopy-preparation of human normal $(\mathbf{A})$ and thrombasthenic (B) platelets spreaded on immobilised collagen. Thrombasthenic platelets show a spreading defect. C Flow cytometric analysis of annexin-V binding to phosphatidylserine on thrombin-stimulated gel-filtered platelets from a patient with Glanzmann's thrombocytopenia and from a healthy control person in vitro. D Formation of thrombin induced platelet-monocyte associates (expressed as platelet-positive monocytes in percent of all detected monocytes) in citrateanticoagulated whole blood from a patient with Glanzmann's thrombocytopenia and from a control person in vitro, quantified by flow cytometry. Activated platelets with reduced GPIIb-IIIa function (either caused by an antiplatelet drug or caused by an inherited disease, as shown in this figure), bind monocytes more eagerly.
A

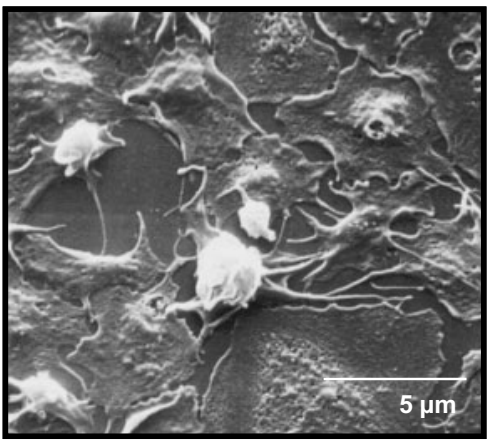

B
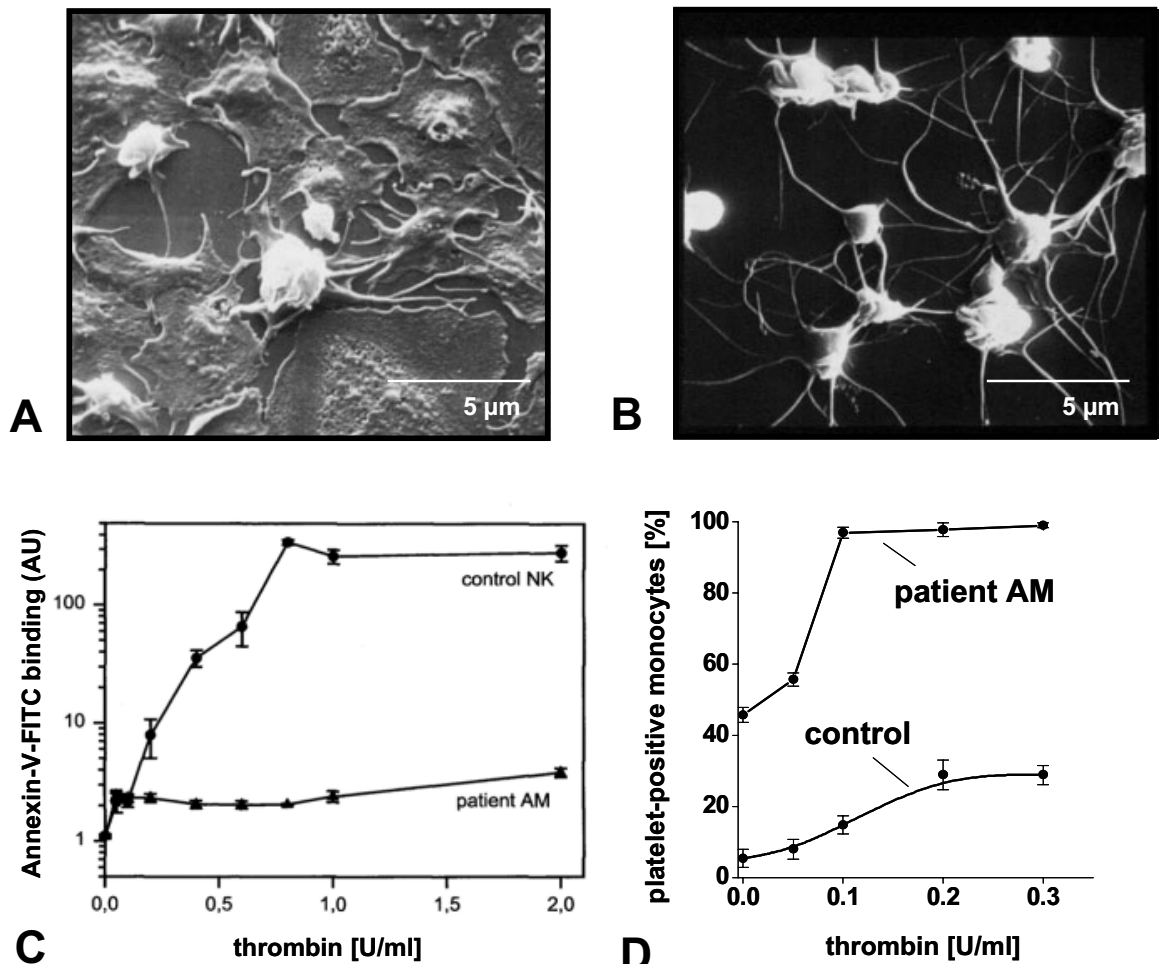

proteolysis. Valve replacement led to resolution of bleeding [30].

In addition to acquired vWD, impaired platelet adhesion to the subendothelium in uraemia may be due to proteolytic degradation of GPIb to soluble glycocalicin [31]. Inhibition of interactions between fibrinogen and GPIIb/IIIa caused by uraemic toxins, leading to conformational changes in GPIIb/ IIIa, may be discussed to be causative for platelet adhesion defects in uraemic patients. Also structural changes of the adhesive substrate TSP-1 contributing to impaired subendothelial platelet adhesion may be involved in uraemia [32].

Some cases of autoimmune disorders, including systemic lupus erythematosus, rheumatoid arthritis or idiopathic thrombocytopenic purpura (ITP) are associated with production of autoantibodies, mainly against platelet GPIb, GPIIb/IIIa, GPIa/ IIa and GPVI. These autoantibodies may coat platelets and therefore inhibit platelet adhesion competitively and induce increased platelet removal in the spleen facilitating thrombocytopenia [33-35]. In patients with platelet counts persistently below $30 \times 10^{9} / 1$, treatment with corticosteroids, and/or intravenous immunoglobin or anti-D may be required.

Platelet adhesion defects are also associated with monoclonal gammopathies, including multiple myeloma and Waldenström's macroglobulinaemia. Very high gamma globulin concentrations may lead to platelet coating with paraproteins/ monoclonal IgG via binding to platelet Fc receptors with subsequent blocking of interactions between platelet receptors and matrix/plasma proteins. However, in some cases the para- protein bound specifically to vWF resulting in acquired vWD [36]. Plasmapheresis and chemotherapy are usually applied for treatment of bleeding complications in patients with paraprotein disorders.

As a result of dysmegakaryocytopoiesis, platelets in patients with myelodysplastic syndromes are often dysfunctional with abnormal glycoprotein patterns, and acquired BSS has been reported [37].

Vitamin C deficiency can also lead to platelet adhesion defects. This deficiency diminishes the synthesis of hydroxyproline and therefore of collagen, leading to defective platelet adhesion to the vessel wall. However, platelet in vitro function is normal. Gingival, subcutaneous and muscle bleeding associated with perifollicular petechiae occur. This disorder can be cured by oral administration of vitamin $\mathrm{C}$ for some weeks [38].

Drugs such as phosphodiesterase inhibitors or dipyridamole, which increase platelet inhibitory intracellular cAMP levels, are used in the prevention of arterial and venous thrombosis and inhibit platelet adhesion to collagen and to the subendothelium. For details the reader is referred to the review from Ahrens et al. [125] in this issue.

\section{Defects of Platelet Spreading}

During platelet adhesion, multiple interactions between specific platelet receptors and subendothelial matrix proteins induce receptor clustering, leading to platelet activation. Subse- 
quent inside-out signalling mediates the activation of the integrin GPIIb/IIIa and a radical change of cytoskeleton structures leading to shape change, formation of pseudopodiae and platelet spreading. Spreaded platelets have multiplied their surface compared to resting platelets, facilitating effective governess of the damaged vessel during wound healing (fig. 2A).

A number of disorders have been described with abnormal platelet structural or cytoskeletal proteins. Inherited disorders include disorders associated with macrothrombocytopenia, mutations in the $M Y H-9$ gene (mutations in non-muscle myosin heavy chain IIa) and platelet sphaerocytosis [39]. Platelets from patients with Glanzmann's thrombocytopenia (see below) show impaired spreading on a collagen matrix in vitro, too (fig. 2B), indicating a functional role of GPIIb/IIIa in specific changes of cytoskeleton structures [40].

Acquired disorders which are associated with impaired platelet spreading include predominantly disorders which affect megakaryocytopoiesis like myelodysplastic syndromes (see above). Differential analysis of platelet spreading defects can only be performed using special light microscopy and electron microscopy devices (fig. 2).

\section{Defects of Platelet Fibrinogen Binding / Primary Aggregation}

Platelet adhesion leads to clustering of specific receptors interacting with subendothelial matrix proteins followed by activation of the integrin GPIIb/IIIa via inside-out-signalling. Conformational changes in GPIIb/IIIa enable binding of soluble fibrinogen which cross-links further platelets, leading to recruitment of additional platelets and aggregation. Under high shear conditions (e.g. arterial stenotic vessels) activated platelet GPIIb/IIIa is able to interact with plasma vWF leading to vWF-mediated platelet aggregation [1]. Disorders affecting fibrinogen or shear-induced vWF binding to GPIIb/ IIIa are characterised by impaired platelet-platelet interaction and primary aggregation.

\section{Hereditary Disorders}

Few patients with deficient or dysfunctional GPIIb/IIIa receptor complex (Glanzmann's thrombasthenia $(G T)$, autosomal recessive inheritance) show prolonged bleeding time, mucocutaneous bleeding, epistaxis, subcutaneous haematoma, petechiae and purpura, but normal platelet count and morphology. Heterozygotes usually do not have bleeding symptoms. Analysis of affected individuals has provided invaluable insights into the structure-function relationship of the GPIIb/ IIIa receptor. The hallmark of GT is reduced or absent platelet aggregation in response to all physiologic platelet agonists, and even the primary wave of aggregation is absent.
However, ristocetin-induced platelet agglutination/aggregation is normal. GT is caused by mutations in the genes encoding GPIIb or GPIIIa leading to loss, reduction or qualitative abnormalities of these glycoproteins. Thus, the extent of expressed GPIIb/IIIa and the content of fibrinogen in the platelet $\alpha$-granule may vary (type I $<5 \%$ GPIIb/IIIa surface expression, type II about 10-20\% GPIIb/IIIa surface expression and type III 60-100\% dysfunctional GPIIb/IIIa surface expression) [41]. Differential diagnosis of GT requires quantitative and qualitative flow cytometric analysis of platelet GPIIb/IIIa using monoclonal antibodies against specific epitopes of the receptor complex or the subunits. In addition, molecular characterisation of the individual mutation pattern in GPIIb/IIIa of GT patients may be helpful in prenatal and family diagnosis.

Platelet transfusion is used as treatment for severe bleeding in GT. However, platelet transfusions may result in the development of autoantibodies to GPIIb/IIIa and/or to human leucocyte antigens (HLA), leading to platelet refractoriness. Recombinant FVIIa has been shown to be effective in GT patients and is approved in the European Union for the treatment of GT patients with platelet antibodies and platelet refractoriness [42].

Congenital disorders of plasma and/or platelet fibrinogen are rare and consist of either absent (afibrinogenaemia, autosomal recessive disorders), low fibrinogen (hypofibrinogenaemia, autosomal recessive disorders), abnormal fibrinogen (dysfibrinogenaemia, in most cases autosomal dominant disorders) or both. Dysfibrinogenaemia is asymptomatic in $55 \%$ of cases, with $25 \%$ having bleeding tendency and $20 \%$ thrombotic tendency. Patients with afibrinogenaemia and severe hypofibrinogenaemia show mild to severe bleeding tendency associated with prolonged bleeding time and similar bleeding symptoms and aggregation defects, like GT patients $[43,44]$. Specific laboratory tests, including determination of plasma or platelet fibrinogen, flow cytometric analysis of platelet surface glycoproteins as well as agonist-induced platelet binding capacity for internal and external fibrinogen, fibrinogen 2D-electrophoresis, fibrinogen and GPIIb or GPIIIa gene analysis are used to diagnose GT and afibrinogenaemia/dysfibrinogenaemia. In contrast to GT, patients with afibrinogenaemia/dysfibrinogenemia require haemotherapy with fibrinogen products.

\section{Acquired Disorders}

Acquired disorders in fibrinogen (dysfibrinogenaemia) are sometimes caused by liver disease, biliary tract disease and certain malignancies, such as hepatoma and renal cell carcinoma $[45,46]$ In addition, it has been reported that patients who underwent organ (e.g. liver) or stem cell transplantation may develop dysfibrinogenaemia [47, 48]. Besides classical screening tests, e.g. thrombin time, reptilase time, fibrinogen activi- 
ty/antigen ratio, automatically thromboelastography (TEG system) has been developed for global analysis of whole blood coagulation and fibrinolysis.

There are several systemic diseases (disseminated intravascular coagulation, hepatic disease, sepsis, and trauma) which may be associated with hyperfibrinolytic reactions and with a significant increase of fibrinogen/fibrin degradation products $(F D P)$. It has been shown that particularly fragments $\mathrm{D}$ and $\mathrm{E}$ have a high affinity for platelet membranes and compete with fibrinogen for platelet receptors, thus impairing aggregation. However, serum FDP levels may not be well correlated with reduced platelet aggregation [49, 50].

Patients with acute leukaemia and myelodysplastic syndromes may show platelet aggregation characteristics of GT. Myelodysplastic syndromes may be associated with abnormal GPIIb as a result of dysmegakaryopoiesis, and deficient GPIIb/IIIa production has been observed in acute promyelocytic leukaemia [51]. In chronic ITP many antibodies are directed against GPIIb/IIIa, which may block interaction between fibrinogen and GPIIb/IIIa and therefore inhibit platelet aggregation [52].

In some patients with paraprotein disorders the paraprotein bound specifically to platelet membrane GPIIIa which resulted in acquired GT [53].

Perioperative substitution of dextran or hydroxyethyl starch for haemodilution has been reported to presumably be associated with impaired platelet aggregation. Hydroxyethyl starch is able to coat platelets by unspecific binding to the platelet surface, therefore blocking GPIIb/IIIa-fibrinogen interaction [54]. Bleeding complications as a result of haemodilution requires its discontinuation.

Due to its critical role in mediating platelet aggregate formation, GPIIb/IIIa has become a primary target for the development of antithrombotic agents [125].

It has been proposed that uraemic toxins inhibit the binding of fibrinogen to GPIIb/IIIa. In addition, uraemic patients may show significant reduction of platelet fibrinogen [55].

\section{Defects of Platelet Signal Transduction}

Platelet activation is the result of tight regulated intracellular responses due to ligation of platelet agonists with receptors on the platelet surface with subsequent receptor clustering. One important signalling cascade is characterised by agonist (e.g. ADP, thrombin, thromboxane A2 (TXA2), epinephrine, platelet-activating factor (PAF)) induced activation of distinct G-protein receptors. The interaction between the G-protein receptors and the key intracellular effector enzymes are mediated by a group of guanosine triphosphate(GTP)-binding proteins which are regulated by GTP.

Signalling through receptors coupled to the Gq-family of Gproteins (protease-activated receptor 1 (PAR1), PAR4, TxA 2 receptor, 5-HT2A receptor) leads to activation of PLC. PLC catalyses the hydrolysis of phosphatidylinositolbisphosphate (PIP2) to inositol triphosphate (IP3) which induces the mobilisation of $\mathrm{Ca}^{2+}$ from the dense tubuli system. An increase in intracellular $\mathrm{Ca}^{2+}$ is associated with a phosphorylation of the myosin light chain by myosin light chain kinase, a process that is necessary for shape change. In addition, receptor signalling through Go12/13-proteins (PAR1, PAR4) also contributes to shape change [56]. Granule secretion is one relevant process in response to $\mathrm{Ca}^{2+}$ mobilisation, which leads to release of ADP from the dense bodies. ADP binds back to $\mathrm{P}_{2} \mathrm{Y}_{12}$ and amplifies platelet activation [57]. Another activation-enhancing pathway is characterised by the synthesis and release of $\mathrm{TxA}_{2}$ which results from $\mathrm{Ca}^{2+}$-dependent mobilisation of arachidonic acid by phospholipase $\mathrm{A} 2$ and subsequent metabolisation through the cyclooxygenase $(\mathrm{CO})$ and $\mathrm{TxA}_{2}$ synthase.

There are some patients who have hereditary abnormalities in early signal transduction events, e.g. G-protein activation, defects in phospholipase $\mathrm{C}$ - $\beta 2$ activation, $\mathrm{Ca}^{2+}$-mobilisation and protein phosphorylation.

\section{Hereditary Defects in G-Protein Activation}

Patients with deficiency in specific GTP-binding proteins $\left(\mathrm{G} \alpha_{\mathrm{q}}, \mathrm{G} \alpha_{\mathrm{i} 1}\right)$ have been described with mild to moderate bleeding disorders. Platelets from these patients show abnormal aggregation and secretion in response to several agonists. Platelets deficient in $\mathrm{G} \alpha_{\mathrm{q}}$ had diminished GTPase activity and abnormalities in the downstream events of GPIIb/IIIa activation, $\mathrm{Ca}^{2+}$ mobilisation and release of arachidonic acid [58]. In contrast, platelets deficient in $\mathrm{G \alpha}_{\mathrm{i} 1}$ (mediating inhibition of adenylyl cyclase and cAMP levels) showed normal $\mathrm{G} \alpha_{\mathrm{q}}$-mediated responses, including activation of PLC- $\beta 2, \mathrm{Ca}^{2+}$ mobilisation and pleckstrin phosphorylation, but fail to inhibit forskolin-stimulated increase in cAMP levels within the platelets [59].

Hereditary Defects in Phospholipase C- $\beta 2$ Activation, in $\mathrm{Ca}^{2+}$ Mobilisation and in Protein Phosphorylation

One patient with impaired platelet PLC activation had decreased platelet PLC- $\beta 2$ protein levels and showed impaired aggregation and secretion responses, decreased IP3 and diacylglycerol formation, diminished $\mathrm{Ca}^{2+}$ peak concentrations and pleckstrin phosphorylation [60].

Activation of PKC- $\theta$, a serine- and threonine-specific protein kinase, regulates central processes of platelet activation, including activation of GPIIb/IIIa, pleckstrin phosphorylation and granule secretion. In some patients deficiency in platelet PKC- $\theta$ resulted in mucocutaneous bleeding, mild thrombocytopenia and impaired agonist-induced platelet aggregation and dense granule secretion. Agonist-induced activation of 
GPIIb/IIIa as well as phosphorylation of pleckstrin and myosin light chain was reduced [61].

Other studies reported of patients with defects in phosphatidylinositol metabolism and protein phosphorylation. However, the primary protein abnormalities are not known [62]. Most of these patients require only rarely or infrequently any therapy.

Patients with congenital deficiencies in intracellular enzymes of the arachidonic acid pathway and of TXA2 synthesis (e.g. impaired liberation of arachidonic acid, cyclooxygenase deficiency, TXA2 synthase deficiency) have been described who show platelet function abnormalities as has been observed in storage pool disease (see below) [63, 64].

\section{Acquired Defects}

Uraemic patients had usually increased plasma levels of prostacyclin which induce a receptor-mediated increase of platelet intracellular cAMP levels [65]. In addition, platelets from uraemic patients produce increased levels of NO associated with increased NO synthase activity which result in increased intracellular cGMP levels. High concentrations of cyclic mononucleotides as second messengers lead to a decrease in IP3 synthesis and $\mathrm{Ca}^{2+}$ mobilisation, resulting in reduction of platelet activation [66]. Bleeding tendencies of uraemic patients correlate with the activity of platelet NO synthase [67]. Furthermore, a significant decrease in the platelet production of TXA 2 and prostaglandin could be observed in uraemic patients [68]. The mechanisms involved are not known, but uraemic toxins may contribute to this signal transduction defect.

Dysmegakaryocytopoiesis associated with leukaemia and myeloproliferative syndromes may also lead to cyclooxygenase and/or thromboxane synthetase deficiency [69].

A number of antiplatelet drugs affect distinct platelet signalling pathways, including acetylsalicylic acid, phosphodiesterase inhibitors and non-steroidal anti-inflammatory drugs as well as furosemide and nitrofurantoin. Acetylsalicylic acid acts as irreversible platelet cyclooxygenase-1 acytelator/inhibitor leading to impaired TXA2 production [70]. Traditional non-steroidal anti-inflammatory drugs (e.g. ibuprofen, indomethacin, and phenylbutazone) can inhibit thromboxanedependent platelet function by competitive, reversible inhibition of platelet cyclooxygenase-1 [71]. Phosphodiesterase inhibitors and a number of prostaglandins induce elevation of cAMP levels within the platelets. Intake of large amounts of ethanol impairs TXA2 production due to inhibition of prostaglandin endoperoxide synthesis which may be associated with morphological abnormalities. The effect of alcohol on platelets is reversible [72].

Diets, rich in eicosapentaenoic acid (e.g. fish oil), may lead to decreased TXA2 synthesis, platelet dysfunction and slight prolongation of the bleeding time due to replacement of phos- pholipid arachidonate by phospholipids rich in eicosapentaenoic acid which is a poor substrate for TXA2 synthesis [73, 74].

\section{Defects in Agonist-Receptor Coupling}

ADP is the prominent amplifier of initial platelet activation [75]. There are two important ADP receptors on the platelet surface. The Gq-coupled $\mathrm{P}_{2} \mathrm{Y}_{1}$ receptor mediates mobilisation of $\mathrm{Ca}^{2+}$, shape change and transient aggregation. The Gi-coupled $\mathrm{P}_{2} \mathrm{Y}_{12}$ receptor is supposed to potentiate platelet secretion and to be involved in sustained irreversible formation of large aggregates. Enzymatical conversion of released ADP to inactive AMP by endothelial and monocyte ecto-ADPase/ CD39 limits platelet activation by ADP. A description of a patient with congenital $P 2 Y_{1}$ defect was given by the group of Oury et al. [76] while several $P 2 Y_{12}$ deficiencies have been described [77, 78]. A detailed, recent review on inherited and acquired abnormalities of the platelet $\mathrm{P} 2$ receptors is given by Cattaneo [79].

It has been shown that epinephrine signalling through Gqcoupled $\alpha 2$ a receptor stimulation shares the final part of the $\mathrm{P}_{2} \mathrm{Y}_{12}$ receptor signalling pathway. This finding might be important to understand the effect of epinephrine on clopidogrel-treated platelets.

Collagen receptor deficiencies are discussed in the adhesion chapter (see above).

\section{Defects of the Release Reaction}

Platelets contain three types of granules: the dense bodies, the $\alpha$-granules and the lysosomes. On platelet activation, the contents of these granules are secreted by an exocytotic process. On platelet activation platelets release arachidonic acid from phospholipids by phospholipase A2. The free arachidonic acid is converted by the cyclooxygenase- 1 to prostaglandins $\mathrm{G} 2$ and $\mathrm{H} 2$ while the thromboxane synthetase forms TXA2. Some of the secreted products induce further platelet activation as a positive feedback, e.g. ADP, TXA2 and serotonin [80].

About $50 \%$ of platelet ADP is stored in the dense bodies (storage pool), which are released after platelet activation, but cannot be refilled. In contrast, the metabolic pool of adenine nucleotides, which is localised in the cytoplasm but not connected to the dense bodies, is able to synthesise new ADP but cannot be released. Serotonin (5-hydroxytryptamin, 5-HT), a well known strong vasoconstrictor, binds to the Gq-coupled 5HT2A receptor and amplifies the platelet response together with ADP. In addition, serotonin may play a procoagulant role in augmenting the retention of procoagulant proteins like fibrinogen and TSP-1 on the platelet surface [81]

Dense body deficiencies are not a homogenous group of disorders. Some rare patients have a deficiency of granule stores 
Fig. 3. Platelet function defects in storage pool disease. A Transmission electron microscopy of section of a normal platelet (MT = marginal microtubules; $\mathrm{G}=\alpha$-granules; $\mathrm{M}=$ mitochondrion; $\mathrm{SCS}$ = surface-connected system; DTS = dense tubular system; DB = dense bodies, left panel). In transmission electron microscopy of a section of a gray platelet (right panel), no characteristic profiles of $\alpha$-granules are visible; several $\alpha$-granules show an electron lucent matrix or are small in dimension (i-G). The bar represents $1 \mu \mathrm{m}$. Picture kindly provided by E. Morgenstern, Homburg Saar. B Flow cytometric analysis of $\mathrm{Ca}^{2+}$ ionophore(A 23187)induced FVa expression on the surface of gelfiltered platelets from a patient with gray platelet syndrome and from a control person in vitro. FVa, stored in the $\alpha$-granules of control platelets, binds to the surface of activated platelets. C Formation of thrombin induced platelet-monocyte associates (expressed as platelet-positive monocytes in percent of all detected monocytes) in citrate-anticoagulated whole blood from two patients (P1, P2) with Gray platelet syndrome and from a control person in vitro, quantified by flow cytometry. D Analysis of mepacrine uptake (ex vivo) and mepacrine release in response to thrombin (in vitro) of platelets from a patient with $\delta$-storage pool deficiency and from a control person using flow cytometry.

\section{A}
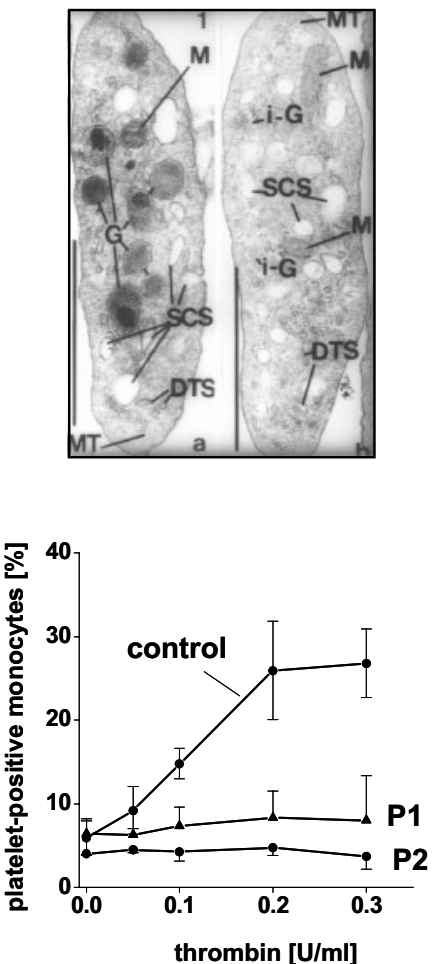
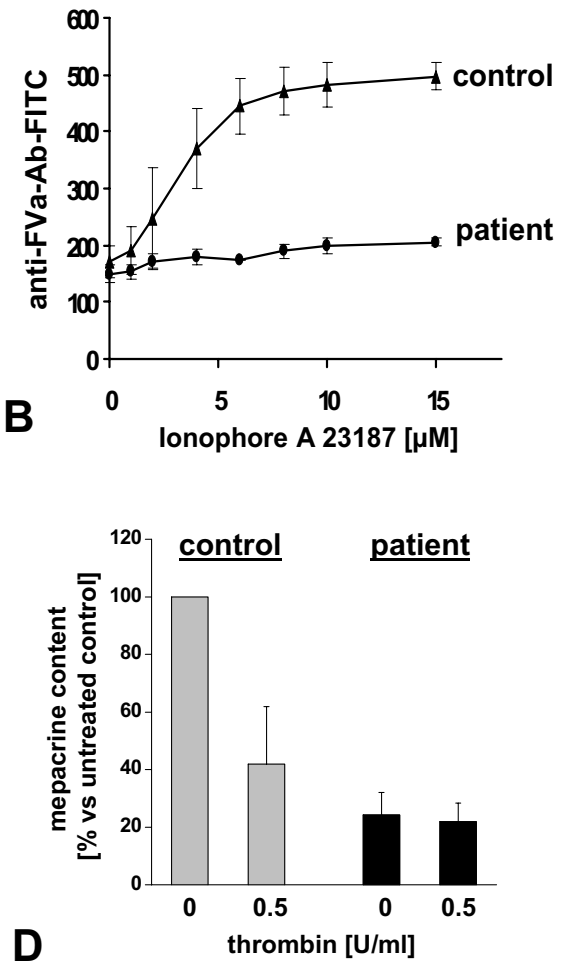

per se (storage pool deficiency). In $\delta$-storage pool deficiency, the platelets are deficient in dense bodies or the dense body contents, like ATP, ADP and serotonin, are decreased (fig. 3D). $\delta$-Storage pool deficiency has been reported in association with other inherited disorders such as Hermansky-Pudlak syndrome, Chediak-Higashi syndrome and Wiskott-Aldrich syndrome [82].

Acquired deficiencies of dense bodies or dense granular contents are seen occasionally in patients with chronic ITP, systemic lupus erythematosus and autoimmune haemolytic anaemia [83]. An impaired secretion as a result from aberrations in the signal transduction that regulates the release of granule contents is more common.

The $\alpha$-granules contain large adhesive proteins (vWF, TSP-1, vitronectin, fibronectin), mitogenic factors (PDGF, VEGF, TGF- $\beta$ ), coagulation factors (FV, FVII, FXI, FXIII) and protease inhibitors (protein $\mathrm{C}$, plasminogen-activator-inhibitor 1 (PAI-1), TFPI), which are released immediately after platelet activation. Some of the $\alpha$-granule proteins are synthesised by megakaryocytes (TSP-1 [84], $\beta$-thromboglobulin, platelet factor $4(\mathrm{PF}-4)$ ); others are endocytosed from the plasma (immunglobulins, fibrinogen, vitronectin). Various glycoproteins, for example P-selectin (CD62P), are exclusively localised on the $\alpha$-granule membrane in resting platelets. Upon secretion, the membrane of the $\alpha$-granule fuses with the plasma membrane and exposes CD62P on the platelet surface. P-selectin mediates platelet binding to neutrophils and monocytes [85]. Leukocytes are able to roll on platelets, which are immo- bilised on the sub-endothelium, in a P-selectin-dependent manner [86].

Platelets with gray platelet syndrome have a deficiency in $\alpha$-granule content proteins, and therefore all proteins that are produced by the megakaryocytes and packed into the $\alpha$-granules, e.g. TSP-1, PF-4, and thromboglobulin are missing [87]. These platelets appear gray on the peripheral blood smear, are much larger than normal platelets, and secretion and aggregation, especially in response to thrombin, are impaired (fig. 3A,B). Local infections of wounds occur very often in these patients. Membranes of abnormal precursor granules, containing P-selectin, are present in gray platelets.

In the ARC (arthrogryposis, renal dysfunction and cholestasis) syndrome, platelets present negligible amounts of P-selectin on their surface, and no $\alpha$-granule membranes are found by electron microscopy [88].

The Quebec platelet disorder $(Q P D)$ is an autosomal dominant platelet disorder associated with delayed bleeding and $\alpha$-granule protein degradation [89].

Acquired defects in storage pool release are heterogeneous. They can be caused by many different underlying diseases, such as cardiopulmonary bypass surgery, immune-mediated release, drugs (storage deficiency: among others reserpine, methysergide, tricyclics, phenothiazines; defective release: e.g. aspirin and other non-steroidal anti-inflammatory drugs), platelet dyspoiesis (e.g. leukaemia, myeloproliferative disorders), ethanol and even diet. An acquired defect with $\alpha$-granule 
depletion has been described in patients during open-heart and pump-oxygenator bypass surgery [90].

Acquired defects in dense granule secretion and thromboxane formation are described in the chapter 'Defects of Platelet Signal Transduction' (see above). Thromboxane formation is inhibited by aspirin and other non-steroidal anti-inflammatory drugs by acting on the platelet cyclooxygenase I. Aspirin irreversibly inactivates the cyclooxygenase-1. Platelets cannot replenish the enzyme by new synthesis, and therefore TXA2 formation is inhibited for the lifetime of the affected platelet [70]. Also diet can affect TXA2 formation. For example, in the so called Eskimo diet, based mainly on fish consumption, the eicosapentaenoic acid replaces the arachidonic acid in the membrane. This leads to decreased TXA2 synthesis and a slightly prolongation in bleeding time [73]. If solely fish consumption is superimposed on another covered platelet defect, spontaneous bleeding tendency can occur (Jurk and Kehrel, unpublished).

In ethanolic patients without liver disease, high amounts of alcohol induce several defects in platelets, including decreased rate of synthesis of prostaglandin endoperoxides and thus impaired thromboxane formation.

Patients with defects in dense body contents, dense body release reaction or in TXA2 formation have a markedly decreased and absent primary wave of aggregation induced by low concentrations of ADP and epinephrine, respectively.

\section{Disorders of Platelet-Procoagulant Activity}

During secondary haemostasis the amplification of platelet stimulation leads to procoagulant activity, thrombin generation, and formation of a stable platelet-fibrin plug with subsequent clot retraction. The platelet membrane contains a specific lipid assembly site and receptors with high-affinity binding sites for clotting factors, which form a favoured preferential and specialised locus to induce and modulate secondary haemostatic processes [91]. The plasma membrane of platelets consists predominantly of phospholipids (about 70\%), cholesterol and glycolipids. The major phospholipids are phosphatidylcholine (PC), sphingomyeline (SphM), phosphatidylethanolamine (PE), phosphatidylserine (PS) and phosphatidylinositole (PI). They are localised asymmetrically in the plasma membrane, with a higher concentration of SphM and PC in the outer leaflet and of PE and acetylated arachidonic acid in the inner leaflet [92]. Platelet activation is associated with a flip-flop move of anionic phospholipids, e.g. PS, from the inner to the outer leaflet, leading to an increase of PS from 2 to $12 \%$ of the phospholipid content. The exposure of anionic phospholipids on the platelet surface can be monitored by labelling of platelets with annexin $\mathrm{V}$, a specific ligand for aminophospholipids [93]. The exposure of PS on aggregated platelets provides a catalytic surface for procoagulant processes, enabling thrombin generation at the site of injury [94].
In the cell-based model of coagulation, small amounts of thrombin are built on the surface of a tissue factor-presenting cell - a fibroblast or an activated monocyte or an activated endothelial cell. These amounts of thrombin are not able to produce a stable fibrin clot, but are high enough to activate platelets. Activated platelets can then bind coagulation factors and cofactors via $\mathrm{Ca}^{2+}$ and by specific receptors [95, 96].

Several platelet protein receptors have been identified in the last few years. FXI, for example, binds with very high affinity to the leucine-rich repeat domain of GPIb $\alpha$ [97]. The plateletbound cofactors FV and FVIII are protected against cleavage by activated protein $\mathrm{C}$ [98]. On the platelet surface the Xase complex and the prothrombinase complex have optimal conditions [99]. The concerted action of coagulation factors yield in a burst of thrombin formation on the platelet surface so that a stable fibrin clot can be formed [100, 101].

In the very rare inherited Scott's syndrome platelets do not express PS on the platelet outer membrane leaflet after activation. Platelets undergo normal adhesion, secretion and aggregation but do not support assembly of the coagulation factors. These platelets lack scramblase activity, but the specific mutations have not been defined [102]. Inverse conditions, the Stormorken's syndrome, have been described by Stormorken et al. [103]. In this disorder platelets are constitutively activated and express PS without prior in vitro activation. A defect in platelet procoagulant activity has also been described in Bernard-Soulier platelets.

Since we measure the burst on thrombin formation on the platelet surface (endogenous thrombin formation in plateletrich plasma, binding of coagulation factors to platelets), we have seen several patients with defects in the interaction between coagulation factors and its protein receptors on the platelet surface, with clear bleeding symptoms. We suggest that these new kind of disorders are just the tip of an iceberg and that many of our bleeding patients have problems with the procoagulant activity of their platelets that is overseen by the classical tests so far.

\section{Defects in Clot Retraction}

Clot retraction is dependent on fibrin(ogen) and integrin $\alpha_{\mathrm{IIb}} \beta_{3}$ and therefore absent in $\alpha_{\mathrm{IIb}} \beta_{3}$-deficient Glanzmann platelets or in afibrinogenaemia. However, only a subset of $\alpha_{\text {Ibis }} \beta_{3}$-blocking antibodies or peptides were able to inhibit retraction, suggesting a differential engagement of $\alpha_{I b i s} \beta_{3}$ in fibrin clot retraction versus aggregation [104].

\section{Association between Platelets and Leucocytes and Microparticle Formation}

Besides homotypic platelet interactions, activated platelets bind preferentially to leucocytes. Heterotypic association be- 
Table 2. Platelet function tests by flow cytometry

Quantification of main agonist-receptors

Dose-dependent induction of fibrinogen binding by platelet agonists (e.g. ADP, arachidonic acid, epinephrine, collagen, thrombin, PAR-1/PAR-4 activating peptides, thromboxane) and vWF binding by ristocetin (or botrocetin)

Dose-dependent induction of P-selectin surface expression by platelet agonists (e.g. ADP, arachidonic acid, epinephrine, collagen, thrombin,

PAR-1/PAR-4 activating peptides, thromboxane) as marker of $\alpha$-granule secretion

Dose-dependent induction of CD63 surface expression by platelet agonists (e.g. ADP, arachidonic acid, epinephrine, collagen, thrombin,

PAR-1/PAR-4 activating peptides, thromboxane) as a marker of dense bodies/lysosome secretion

Mepacrine uptake into the dense bodies and release induced by platelet agonists

CD40L surface expression induced by platelet agonists (collagen, thrombin) as a marker of exocytosis from internal stores

Annexin $\mathrm{V}$ binding to negatively charged phospholipids on the platelet surface after platelet activation with collagen plus thrombin

Binding of coagulation factors to activated platelets

Detection of intracellular as well as extracellular posttranslational modifications in proteins (e.g. phosphorylation, free thiols, glutathionylation, S-nitrosylation)

Quantification of associates between platelets and leucocytes

Activation-dependent cleavage of platelet cell surface proteins (e.g. PAR-1, PAR-4, GPIb, GPV, GPVI, CD36, CD40L)

Platelet microparticle formation

Serotonin release and rebinding to the platelet surface

tween platelets and leucocytes leads to a new type of cell complexes with new characteristics as reviewed by McEver [105]. Increased levels of platelet-leucocyte associates have been found in the circulation of patients with severe trauma [106], sepsis [106], stroke [107], heart attack [108], diabetes mellitus type I [109] and asthma [110].

Under medication with GPIIb/IIIa antagonists or in Glanzmann's thrombasthenia, platelet activation leads to higher numbers of associates between platelets and leucocytes (fig. $2),[111]$. In patients with $\alpha$-granule defects fewer associates are formed (fig. 3C). A decrease in platelet-leucocyte associate formation is also found in patients with very severe multiple organ dysfunctions [112].

Strong agonists like collagen in combination with thrombin or complement (C5b-9) induce shedding of microparticles from the platelet surface. This 'budding' process is due to $\mathrm{Ca}^{2+}$-mediated activation of calpain and leads to vesicles containing exclusively intra-cytoplasmatic substances [113]. These particles are procoagulant and show similar surface expression of activation-dependent adhesion molecules (P-selectin, CD40L) as stimulated platelets. Platelet-derived microparticles are found to be increased in the circulation of patients with sepsis or after cardiopulmonary bypass and are thought to be associated with thrombotic diseases [114]. Platelet aggregation is a prerequisite for microparticle formation [115]. Therefore microparticle formation is disturbed in all platelet aggregation defects.

\section{Approach to Diagnosis}

There is no test that identifies all problems related to platelet function. The basis of all diagnoses of platelet function defects is a detailed case and family history. An approach for diagnosing platelet disorders is given in figure 1 . In the past, the pri- mary screen for platelet function defects has been the bleeding time. However, the bleeding time is not very sensitive or specific, and the reproducibility depends on the skills of the person performing the test. The bleeding time is prolonged in several inherited platelet disorders but, like all other platelet tests studied so far, is not able to predict the likelihood that a patient will bleed excessively during surgery [116].

The PFA-100 (Platelet Function Analyser 100, Dade Behring) has gained acceptance as a device to screen for aspirin effects and to analyse those platelet functions that depend on high shear stress, e.g. platelet interactions with vWF. PFA-100 measures the closure time of citrated blood aspirated at high shear through the central aperture of a nitrocellulose membrane coated with a combination of agonists. The PFA-100 test is not a replacement for bleeding tests.

Platelet secretion and aggregation tests provide evidence for defects, but these parameters are not universally predictive of the severity of bleeding symptoms. The cone and plate(let) analyser (Impact) may be useful to analyse platelet adhesion (see above) and subsequent platelet aggregation on different adhesive substrates under different shear conditions [117]. In contrast to other global tests, also hyperreactivity of platelets is reflected when using this device. Recent data suggests that this device is a reliable tool for the diagnosis of several platelet adhesion and aggregation defects.

More sophisticated tests (listed in fig. 1 and table 2) are very useful to study platelet functions in detail. A drawback is that most of these tests are available only in few specialised laboratories.

\section{Management of Platelet Disorders}

Treatment of acquired platelet function defects always requires the treatment of the underlying disease first. Only in 
pronounced bleeding or high risk of bleeding platelets usually have to be transfused to provide normally functioning platelets. Desmopressin, tranexamic acid and recombinant FVII can also be of value. However, the detailed knowledge of the causal relationship leading to platelet function defects is necessary to choose the right management. Detailed advices for the management of different platelet disorders are given in several reviews on special aspects of platelet disorders [118-121].

\section{Closing Remarks}

The implementation of modern proteomics and transcriptomic technology in platelet studies will further increase our un- derstanding of different platelet functions and gives reason to hope that novel biomarkers can be discovered that help in diagnosing inherited and/or acquired platelet disorders or predicting the susceptibility of individuals to bleeding or to thrombosis $[122,123]$.

Posttranslational modifications of platelet surface proteins, e.g. by redox-reactions, NO and glutathion, modify platelet function [124]. Studies on postranslational modifications of platelets in different disease states will offer deeper insights into platelet disorders in the future.

\section{Acknowledgement}

This work was supported by the DFG SFB 293 Project A6.

\section{References}

1 Ruggeri ZM: Mechanisms of shear-induced platelet adhesion and aggregation. Thromb Haemost 1993; 70:119-123.

2 Jurk K, Clemetson KJ, de Groot PG, Brodde MF, Steiner M, Savion N, Varon D, Sixma JJ, Van Aken H, Kehrel BE: Thrombospondin-1 mediates platelet adhesion at high shear via glycoprotein $\mathrm{Ib}$ (GPIb): an alternative/backup mechanism to von Willebrand factor. FASEB J 2003;17:1490-1492.

$\checkmark 3$ Lam SC, Plow EF, D'Souza SE, Cheresh DA, Frelinger AL, III, Ginsberg MH: Isolation and characterization of a platelet membrane protein related to the vitronectin receptor. J Biol Chem 1989; 264:3742-3749.

4 Hemler ME, Crouse C, Takada Y, Sonnenberg A: Multiple very late antigen (VLA) heterodimers on platelets. Evidence for distinct VLA-2, VLA-5 (fibronectin receptor), and VLA-6 structures. J Biol Chem 1988;263:7660-7665.

5 Bithell TC, Parekh SJ, Strong RR: Platelet-function studies in the Bernard-Soulier syndrome. Ann N Y Acad Sci 1972;201:145-160.

6 Howard MA, Hutton RA, Hardisty RM: Hereditary giant platelet syndrome: a disorder of a new aspect of platelet function. $\mathrm{Br}$ Med J 1973;2: 586-588.

7 Nurden AT, Combrie R, Claeyssens S, Nurden P: Heterozygotes in the Bernard-Soulier syndrome do not necessarily have giant platelets or thrombocytopenia. Br J Haematol 2003;120:716-717.

8 Lopez JA, Andrews RK, Afshar-Kharghan V, Berndt MC: Bernard-Soulier syndrome. Blood 1998; 91:4397-4418

$\checkmark 9$ Kahn ML, Diacovo TG, Bainton DF, Lanza F, Trejo J, Coughlin SR: Glycoprotein V-deficient platelets have undiminished thrombin responsiveness and do not exhibit a Bernard-Soulier phenotype. Blood 1999;94:4112-4121.

10 Ozelo MC, Svirin P, Larina L: Use of recombinant factor VIIa in the management of severe bleeding episodes in patients with Bernard-Soulier syndrome. Ann Hematol 2005;84:816-822.

11 Sadler JE: New concepts in von Willebrand disease. Annu Rev Med 2005;56:173-191.

-12 Sadler JE, for the Subcommittee on von Willebrand Factor of the Scientific and Standardization Committee of the International Society on Thrombosis and Haemostasis: A revised classification of von Willebrand disease. Thromb Haemost 1994;71: $520-525$.
13 Miller JL, Castella A: Platelet-type von Willebrand's disease: characterization of a new bleeding disorder. Blood 1982;60:790-794.

14 Mannucci PM: Treatment of von Willebrand's disease. N Engl J Med 2004;351:683-694.

15 Auger JM, Kuijpers MJ, Senis YA, Watson SP, Heemskerk JW: Adhesion of human and mouse platelets to collagen under shear: a unifying model. FASEB J 2005;19:825-827.

16 Nieuwenhuis HK, Akkerman JW, Houdijk WP, Sixma JJ: Human blood platelets showing no response to collagen fail to express surface glycoprotein Ia. Nature 1985;318:470-472.

17 Kehrel B, Balleisen L, Kokott R, Mesters R, Stenzinger W, Clemetson KJ, van de Loo J: Deficiency of intact thrombospondin and membrane glycoprotein Ia in platelets with defective collagen-induced aggregation and spontaneous loss of disorder. Blood 1988;71:1074-1078.

18 Arai M, Yamamoto N, Moroi M, Akamatsu N, Fukutake K, Tanoue K: Platelets with $10 \%$ of the normal amount of glycoprotein VI have an impaired response to collagen that results in a mild bleeding tendency. Br J Haematol 1995;89:124-130.

19 Moroi M, Jung SM, Okuma M, Shinmyozu K: A patient with platelets deficient in glycoprotein VI that lack both collagen-induced aggregation and adhesion. J Clin Invest 1989;84:1440-1445.

20 Kehrel B, Wierwille S, Clemetson KJ, Anders O, Steiner M, Knight CG, Farndale RW, Okuma M, Barnes MJ: Glycoprotein VI is a major collagen receptor for platelet activation: it recognizes the platelet-activating quaternary structure of collagen, whereas CD36, glycoprotein IIb/IIIa, and von Willebrand factor do not. Blood 1998:91:491-499.

21 Sugiyama T, Okuma M, Ushikubi F, Sensaki S, Kanaji K, Uchino H: A novel platelet aggregating factor found in a patient with defective collagen-induced platelet aggregation and autoimmune thrombocytopenia. Blood 1987;69:1712-1720.

22 Ichinohe T, Takayama H, Ezumi Y, Yanagi S, Yamamura H, Okuma M: Cyclic AMP-insensitive activation of c-Src and Syk protein-tyrosine kinases through platelet membrane glycoprotein VI. J Biol Chem 1995;270:28029-28036.

23 Estes JW: Platelet abnormalities in heritable disorders of connective tissue. Ann N Y Acad Sci 1972; 201:445-450.
4 Casonato A, Pontara E, Vertolli UP, Steffan A, Durante C, De Marco L, Sartorello F, Girolami A: Plasma and platelet von Willebrand factor abnormalities in patients with uremia: lack of correlation with uremic bleeding. Clin Appl Thromb Hemost 2001;7:81-86.

25 Mannucci PM, Remuzzi G, Pusineri F, Lombardi R, Valsecchi C, Mecca G, Zimmerman TS: Deamino8-D-arginine vasopressin shortens the bleeding time in uremia. N Engl J Med 1983;308:8-12.

26 Fabris F, Casonato A, Grazia dB, De Marco L, Girolami A: Abnormalities of von Willebrand factor in myeloproliferative disease: a relationship with bleeding diathesis. Br J Haematol 1986;63: $75-83$.

27 Takahashi H, Nagayama R, Hattori A, Shibata A: Platelet aggregation induced by DDAVP in platelet-type von Willebrand's disease. N Engl J Med 1984;310:722-723.

28 Weinstein M, Ware JA, Troll J, Salzman E: Changes in von Willebrand factor during cardiac surgery: effect of desmopressin acetate. Blood 1988;71: 1648-1655.

29 Meschengieser S, Blanco A, Woods A, Maugeri N, Fernandez J, Dupont J, Lazzari MA: Intraplatelet levels of vWF:Ag and fibrinogen in myeloproliferative disorders. Thromb Res 1987;48:311-319.

30 Yoshida K, Tobe S, Kawata M, Yamaguchi M: Acquired and reversible von Willebrand disease with high shear stress aortic valve stenosis. Ann Thorac Surg 2006;81:490-494.

31 Sloand EM, Sloand JA, Prodouz K, Klein HG, Yu MW, Harvath L, Fricke W: Reduction of platelet glycoprotein Ib in uraemia. Br J Haematol 1991;77: 375-381.

32 Gawaz MP, Ward RA: Effects of hemodialysis on platelet-derived thrombospondin. Kidney Int 1991; 40:257-265.

33 Sohal AS, Gangji AS, Crowther MA, Treleaven D: Uremic bleeding: pathophysiology and clinical risk factors. Thromb Res 2006;118:417-422.

34 Woods VL Jr, Oh EH, Mason D, McMillan R: Autoantibodies against the platelet glycoprotein IIb/ IIIa complex in patients with chronic ITP. Blood 1984;63:368-375. 
35 Deckmyn H, Chew SL, Vermylen J: Lack of platelet response to collagen associated with an autoantibody against glycoprotein Ia: a novel cause of acquired qualitative platelet dysfunction. Thromb Haemost 1990;64:74-79.

-36 Mohri H, Tanabe J, Ohtsuka M, Yoshida M, Motomura S, Nishida S, Fujimura Y, Okubo T: Acquired von Willebrand disease associated with multiple myeloma; characterization of an inhibitor to von Willebrand factor. Blood Coagul Fibrinolysis 1995; 6:561-566.

37 Berndt MC, Kabral A, Grimsley P, Watson N, Robertson TI, Bradstock KF: An acquired Bernard-Soulier-like platelet defect associated with juvenile myelodysplastic syndrome. Br J Haematol 1988;68:97-101.

38 Johnson GJ, Holloway DE, Hutton SW, Duane WC: Platelet function in scurvy and experimental human vitamin C deficiency. Thromb Res 1981;24: 85-93.

-39 Seri M, Cusano R, Gangarossa S, Caridi G, Bordo D, Lo NC, Ghiggeri GM, Ravazzolo R, Savino M, Del Vecchio M, d'Apolito M, Iolascon A, Zelante LL, Savoia A, Balduini CL, Noris P, Magrini U, Belletti S, Heath KE, Babcock M, Glucksman MJ, Aliprandis E, Bizzaro N, Desnick RJ, Martignetti JA: Mutations in MYH9 result in the May-Hegglin anomaly, and Fechtner and Sebastian syndromes. The May-Hegglin/Fechtner Syndrome Consortium. Nat Genet 2000;26:103-105.

40 Weiss HJ, Turitto VT, Baumgartner HR: Further evidence that glycoprotein IIb-IIIa mediates platelet spreading on subendothelium. Thromb Haemost 1991;65:202-205.

41 French DL, Seligsohn U: Platelet glycoprotein IIb/IIIa receptors and Glanzmann's thrombasthenia. Arterioscler Thromb Vasc Biol 2000;20: 607-610.

42 Poon MC, D’Oiron R, Von Depka M, Khair K, Negrier C, Karafoulidou A, Huth-Kuehne A, Morfini M: Prophylactic and therapeutic recombinant factor VIIa administration to patients with Glanzmann's thrombasthenia: results of an international survey. J Thromb Haemost 2004;2:1096-1103.

43 Asselta R, Duga S, Tenchini ML: The molecular basis of quantitative fibrinogen disorders. J Thromb Haemost 2006;4:2115-2129.

44 Weiss HJ, Rogers J: Fibrinogen and platelets in the primary arrest of bleeding. Studies in two patients with congenital afibrinogenemia. N Engl J Med 1971;285:369-374

45 Lane DA, Scully MF, Thomas DP, Kakkar VV, Woolf IL, Williams R: Acquired dysfibrinogenaemia in acute and chronic liver disease. $\mathrm{Br} \mathrm{J}$ Haematol 1977;35:301-308.

46 Dawson NA, Barr CF, Alving BM: Acquired dysfibrinogenemia. Paraneoplastic syndrome in renal cell carcinoma. Am J Med 1985;78:682-686.

47 Cransac M, Carles J, Bernard PH, Malavialle P, Freyburger G, Winnock S, Saric J: Heterozygous protein $\mathrm{C}$ deficiency and dysfibrinogenemia acquired by liver transplantation. Transpl Int 1995;8: 307-311.

48 Mori T, Murata M, Wakui M, Muto A, Ishida A, Tanosaki R, Okamoto S, Ikeda Y: Acquired dysfibrinogenemia following allogeneic bone marrow transplantation. Am J Hematol 1997;56:294-295.

49 Levi M, ten Cate H: Disseminated intravascular coagulation. N Engl J Med 1999;341:586-592.

50 Solum NO, Rigollot C, Budzynski AZ, Marder VJ: A quantitative evaluation of the inhibition of platelet aggregation by low molecular weight degradation products of fibrinogen. Br J Haematol 1973;24:419-434.
51 Yufu Y, Hashimoto M, Muta K, Ideguchi H, Nishimura J, Nawata H: Abnormality of platelet membrane glycoprotein GPIIb in a myelodysplastic syndrome with $3 \mathrm{q}$ inversion presenting with marked dysmegakaryopoiesis. Acta Haematol 1990; 83:107-110.

52 Chong BH, Ho SJ: Autoimmune thrombocytopenia. J Thromb Haemost 2005;3:1763-1772.

53 DiMinno G, Coraggio F, Cerbone AM, Capitanio AM, Manzo C, Spina M, Scarpato P, Dattoli GM, Mattioli PL, Mancini M: A myeloma paraprotein with specificity for platelet glycoprotein IIIa in a patient with a fatal bleeding disorder. J Clin Invest 1986;77:157-164.

54 Deusch E, Gamsjager T, Kress HG, Kozek-Langenecker SA: Binding of hydroxyethyl starch molecules to the platelet surface. Anesth Analg 2003;97: 680-683.

55 Gawaz MP, Dobos G, Spath M, Schollmeyer P, Gurland HJ, Mujais SK: Impaired function of platelet membrane glycoprotein IIb-IIIa in endstage renal disease. J Am Soc Nephrol 1994;5: 36-46.

56 Brass LF: Thrombin and platelet activation. Chest 2003; 124:18S-25S.

57 Hollopeter G, Jantzen HM, Vincent D, Li G, England L, Ramakrishnan V, Yang RB, Nurden P, Nurden A, Julius D, Conley PB: Identification of the platelet ADP receptor targeted by antithrombotic drugs. Nature 2001;409:202-207.

58 Gabbeta J, Yang X, Kowalska MA, Sun L, Dhanasekaran N, Rao AK: Platelet signal transduction defect with Galpha subunit dysfunction and diminished Galphaq in a patient with abnormal platelet responses. Proc Natl Acad Sci U S A 1997; 94:8750-8755.

59 Patel YM, Patel K, Rahman S, Smith MP, Spooner G, Sumathipala R, Mitchell M, Flynn G, Aitken A, Savidge G: Evidence for a role for Galphai1 in mediating weak agonist-induced platelet aggregation in human platelets: reduced Galphai1 expression and defective Gi signaling in the platelets of a patient with a chronic bleeding disorder. Blood 2003; 101:4828-4835.

60 Lee SB, Rao AK, Lee KH, Yang X, Bae YS, Rhee SG: Decreased expression of phospholipase C-beta 2 isozyme in human platelets with impaired function. Blood 1996;88:1684-1691.

61 Sun L, Mao G, Rao AK: Association of CBFA2 mutation with decreased platelet PKC-theta and impaired receptor-mediated activation of GPIIbIIIa and pleckstrin phosphorylation: proteins regulated by CBFA2 play a role in GPIIb-IIIa activation. Blood 2004;103:948-954

62 Lages B, Weiss HJ: Impairment of phosphatidylinositol metabolism in a patient with a bleeding disorder associated with defects of initial platelet responses. Thromb Haemost 1988;59:175-179.

63 Lagarde M, Byron PA, Vargaftig BB, Dechavanne M: Impairment of platelet thromboxane A2 generation and of the platelet release reaction in two patients with congenital deficiency of platelet cyclooxygenase. Br J Haematol 1978;38:251-266.

64 Mestel F, Oetliker O, Beck E, Felix R, Imbach P, Wagner HP: Severe bleeding associated with defective thromboxane synthetase. Lancet 1980;i:157.

65 Vlachoyannis J, Schoeppe W: Adenylate cyclase activity and cAMP content of human platelets in uraemia. Eur J Clin Invest 1982;12:379-381.

66 Remuzzi G, Marchesi D, Livio M, Cavenaghi AE, Mecca G, Donati MB, de Gaetano G: Altered platelet and vascular prostaglandin-generation in patients with renal failure and prolonged bleeding times. Thromb Res 1978;13:1007-1015.
67 Schwarz UR, Walter U, Eigenthaler M: Taming platelets with cyclic nucleotides. Biochem Pharmacol 2001;62:1153-1161.

68 Brunini TM, Yaqoob MM, Novaes Malagris LE, Ellory JC, Mann GE, Mendes Ribeiro AC: Increased nitric oxide synthesis in uraemic platelets is dependent on L-arginine transport via system y(+)L. Pflugers Arch 2003;445:547-550.

69 Okuma M. Uchino H: Altered arachidonate metabolism by platelets in patients with myeloproliferative disorders. Blood 1979;54:1258-1271.

70 Amrein PC, Ellman L, Harris WH: Aspirin-induced prolongation of bleeding time and perioperative blood loss. JAMA 1981;245:1825-1828.

71 Moncada S, Vane JR: Mode of action of aspirin-like drugs. Adv Intern Med 1979;24:1-22.

72 Cowan DH: Effect of alcoholism on hemostasis. Semin Hematol 1980;17:137-147.

73 Dyerberg J, Bang HO: Haemostatic function and platelet polyunsaturated fatty acids in Eskimos. Lancet 1979;ii:433-435.

74 Siess W, Roth P, Scherer B, Kurzmann I, Bohlig B, Weber PC: Platelet-membrane fatty acids, platelet aggregation, and thromboxane formation during a mackerel diet. Lancet 1980;i:441-444.

75 Gachet C: Identification, characterization, and inhibition of the platelet ADP receptors. Int J Hematol 2001;74:375-381.

76 Oury C, Lenaerts T, Peerlinck K, Vermylen J, Hoylaerts MF: Congenital deficiency of the phospholipase $\mathrm{C}$ coupled platelet $\mathrm{P} 2 \mathrm{Y} 1$ receptor leads to mild bleeding disorder. Thromb Haemost 1999;85 (suppl):20.

77 Nurden P, Savi P, Heilmann E, Bihour C, Herbert JM, Maffrand JP, Nurden A: An inherited bleeding disorder linked to a defective interaction between ADP and its receptor on platelets. Its influence on glycoprotein IIb-IIIa complex function. J Clin Invest 1995;95:1612-1622.

78 Cattaneo M, Zighetti ML, Lombardi R, Martinez C, Lecchi A, Conley PB, Ware J, Ruggeri ZM: Molecular bases of defective signal transduction in the platelet P2Y12 receptor of a patient with congenital bleeding. Proc Natl Acad Sci U S A 2003;100: 1978-1983.

79 Cattaneo M: Disorders of platelet function. Abnormalities of the platelet P2 receptors. Pathophysiol Haemost Thromb 2006:35:10-14.

80 Reed GL: Platelet secretory mechanisms. Semin Thromb Hemost 2004;30:441-450.

81 Dale GL, Friese P, Batar P, Hamilton SF, Reed GL, Jackson KW, Clemetson KJ, Alberio L: Stimulated platelets use serotonin to enhance their retention of procoagulant proteins on the cell surface. Nature 2002;415:175-179.

82 Huebsch LB, Harker LA: Disorders of platelet function: mechanisms, diagnosis and management. West J Med 1981;134:109-127.

83 Fuse I: Disorders of platelet function. Crit Rev Oncol Hematol 1996;22:1-25.

84 Kehrel B, Flicker E, Wigbels B, Osterfeld M, van de LJ, Luscher EF: Thrombospondin measured in whole blood - an indicator of platelet activation. Blood Coagul Fibrinolysis 1996;7:202-205.

85 Singbartl K, Forlow SB, Ley K: Platelet, but not endothelial, P-selectin is critical for neutrophil-mediated acute postischemic renal failure. FASEB J 2001;15:2337-2344.

86 Furie B, Furie BC, Flaumenhaft R: A journey with platelet P-selectin: the molecular basis of granule secretion, signalling and cell adhesion. Thromb Haemost 2001;86:214-221. 
87 Nurden AT, Nurden P: The gray platelet syndrome: clinical spectrum of the disease. Blood Rev 2006; DOI10.1016/j.blre.2005.12.003

-88 Lo B, Li L, Gissen P, Christensen H, McKiernan PJ, Ye C, Abdelhaleem M, Hayes JA, Williams MD, Chitayat D, Kahr WH: Requirement of VPS33B, a member of the Sec1/Munc18 protein family, in megakaryocyte and platelet alpha-granule biogenesis. Blood 2005;106:4159-4166.

89 Kahr WH, Zheng S, Sheth PM, Pai M, Cowie A Bouchard M, Podor TJ, Rivard GE, Hayward CP: Platelets from patients with the Quebec platelet disorder contain and secrete abnormal amounts of urokinase-type plasminogen activator. Blood 2001; 98:257-265.

90 Francis JL: Platelet dysfunction detected at high shear in patients with heart valve disease. Platelets 2000;11:133-136.

-91 Monroe DM, Hoffman M, Roberts HR: Platelets and thrombin generation. Arterioscler Thromb Vasc Biol 2002;22:1381-1389.

92 Zwaal RF, Schroit AJ: Pathophysiologic implications of membrane phospholipid asymmetry in blood cells. Blood 1997;89:1121-1132.

93 Dörmann D, Kardoeus J, Zimmermann RE. Flowcytometric analysis of agonist-induced annexin $\mathrm{V}$, factor Va and factor Xa binding to human platelets. Platelets 1998;9:171-177.

94 Sims PJ, Wiedmer T, Esmon CT, Weiss HJ, Shattil SJ: Assembly of the platelet prothrombinase complex is linked to vesiculation of the platelet plasma membrane. Studies in Scott syndrome: an isolated defect in platelet procoagulant activity. J Biol Chem 1989;264:17049-17057.

95 Nesheim ME, Furmaniak-Kazmierczak E, Henin C, Cote G: On the existence of platelet receptors for factor V(a) and factor VIII(a). Thromb Haemost 1993;70:80-86.

96 Bouchard BA, Silveira JR, Tracy PB: On the role of EPR-1 or an EPR-1-like molecule in regulating factor Xa incorporation into platelet prothrombinase. Thromb Haemost 2001;86:1133-1135.

97 Yun TH, Baglia FA, Myles T, Navaneetham D, Lopez JA, Walsh PN, Leung LL: Thrombin activation of factor XI on activated platelets requires the interaction of factor XI and platelet glycoprotein $\mathrm{Ib}$ alpha with thrombin anion-binding exosites I and II, respectively. J Biol Chem 2003;278:48112-48119.

98 Oliver JA, Monroe DM, Roberts HR, Hoffman M: Thrombin activates factor XI on activated platelets in the absence of factor XII. Arterioscler Thromb Vasc Biol 1999;19:170-177.

99 Scandura JM, Walsh PN: Factor X bound to the surface of activated human platelets is preferentially activated by platelet-bound factor IXa. Biochemistry 1996;35:8903-8913.
100 Dormann D, Clemetson KJ, Kehrel BE: The GPIb thrombin-binding site is essential for thrombin-induced platelet procoagulant activity. Blood 2000; 96:2469-2478.

101 Brass LF: More pieces of the platelet activation puzzle slide into place. J Clin Invest 1999;104: 1663-1665.

102 Zwaal RF, Comfurius P, Bevers EM: Scott syndrome, a bleeding disorder caused by defective scrambling of membrane phospholipids. Biochim Biophys Acta 2004;1636:119-128.

103 Stormorken H, Holmsen H, Sund R, Sakariassen KS, Hovig T, Jellum E, Solum O: Studies on the haemostatic defect in a complicated syndrome. An inverse Scott syndrome platelet membrane abnormality? Thromb Haemost 1995;74:1244-1251.

104 Osdoit S, Rosa JP: Fibrin clot retraction by human platelets correlates with alpha(IIb)beta(3) integrin-dependent protein tyrosine dephosphorylation. J Biol Chem 2001;276:6703-6710.

105 McEver RP: Adhesive interactions of leukocytes, platelets, and the vessel wall during hemostasis and inflammation. Thromb Haemost 2001;86: 746-756.

106 Ogura H, Kawasaki T, Tanaka H, Koh T, Tanaka R, Ozeki Y, Hosotsubo H, Kuwagata Y, Shimazu T, Sugimoto H: Activated platelets enhance microparticle formation and platelet-leukocyte interaction in severe trauma and sepsis. J Trauma 2001; 50:801-809.

107 Garlichs CD, Kozina S, Fateh-Moghadam S, Handschu R, Tomandl B, Stumpf C, Eskafi S, Raaz D, Schmeisser A, Yilmaz A, Ludwig J, Neundorfer B, Daniel WG: Upregulation of CD40-CD40 ligand (CD154) in patients with acute cerebral ischemia. Stroke 2003;34:1412-1418.

108 Furman MI, Barnard MR, Krueger LA, Fox ML, Shilale EA, Lessard DM, Marchese P, Frelinger AL III, Goldberg RJ, Michelson AD: Circulating monocyte-platelet aggregates are an early marker of acute myocardial infarction. J Am Coll Cardiol 2001;38:1002-1006.

109 Tschoepe D, Rauch U, Schwippert B: Plateletleukocyte-cross-talk in diabetes mellitus. Horm Metab Res 1997;29:631-635.

110 Pitchford SC, Yano H, Lever R, Riffo-Vasquez Y, Ciferri S, Rose MJ, Giannini S, Momi S, Spina D, O'Connor B, Gresele P, Page CP: Platelets are essential for leukocyte recruitment in allergic inflammation. J Allergy Clin Immunol 2003;112: 109-118.

111 Zhao L, Bath P, Losche W, Heptinstall S: Plateletmonocyte interaction and GPIIb/IIIa blockade. Thromb Haemost 2004;92:888-890.

112 Gawaz M, Dickfeld T, Bogner C, FatehMoghadam S, Neumann FJ: Platelet function in septic multiple organ dysfunction syndrome. Intensive Care Med 1997;23:379-385.
113 Holme PA, Orvim U, Hamers MJ, Solum NO, Brosstad FR, Barstad RM, Sakariassen KS: Shearinduced platelet activation and platelet microparticle formation at blood flow conditions as in arteries with a severe stenosis. Arterioscler Thromb Vasc Biol 1997;17:646-653.

114 Nieuwland R, Berckmans RJ, Rotteveel-Eijkman RC, Maquelin KN, Roozendaal KJ, Jansen PG, ten Have K, Eijsman L, Hack CE, Sturk A: Cell-derived microparticles generated in patients during cardiopulmonary bypass are highly procoagulant. Circulation 1997;96:3534-3541.

115 Sakariassen KS, Holme PA, Orvim U, Barstad RM, Solum NO, Brosstad FR: Shear-induced platelet activation and platelet microparticle formation in native human blood. Thromb Res 1998; 92:S33-S41.

116 Peterson P, Hayes TE, Arkin CF, Bovill EG, Fairweather RB, Rock WA Jr, Triplett DA, Brandt JT: The preoperative bleeding time test lacks clinical benefit: College of American Pathologists' and American Society of Clinical Pathologists' position article. Arch Surg 1998;133:134-139.

117 Savion N, Varon D: Impact - the cone and plate (let) analyzer: testing platelet function and antiplatelet drug response. Pathophysiol Haemost Thromb 2006;35:83-88.

118 Boccardo P, Remuzzi G, Galbusera M: Platelet dysfunction in renal failure. Semin Thromb Hemost 2004;30:579-589.

119 Hassan AA, Kroll MH: Acquired disorders of platelet function. Hematology (Am Soc Hematol Educ Program ) 2005;403-408.

120 Mannucci PM: Platelet von Willebrand factor in inherited and acquired bleeding disorders. Proc Natl Acad Sci U S A 1995;92:2428-2432.

121 Liesner RJ, Machin SJ: ABC of clinical haematology. Platelet disorders. Br Med J 1997;314: 809-812.

122 Macaulay IC, Carr P, Gusnanto A, Ouwehand WH, Fitzgerald D, Watkins NA: Platelet genomics and proteomics in human health and disease. J Clin Invest 2005;115:3370-3377.

123 Dittrich M, Birschmann I, Pfrang J, Herterich S, Smolenski A, Walter U, Dandekar T: Analysis of SAGE data in human platelets: features of the transcriptome in an anucleate cell. Thromb Haemost 2006;95:643-651.

124 Lahav J, Jurk K, Hess O, Barnes MJ, Farndale RW, Luboshitz J, Kehrel BE: Sustained integrin ligation involves extracellular free sulfhydryls and enzymatically catalyzed disulfide exchange. Blood 2002;100:2472-2478.

125 Ahrens I, Schwarz M, Peter K, Bode C: Therapeutic inhibitors of platelet aggregation - from aspirin to integrin blockers. Transfusion Med Hemother 2007;DOI 10.1159/000097664. 